\title{
KONSEP PENDIDIKAN AGAMA ISLAM (PAI) BERBASIS PESANTREN DI LEMBAGA PENDIDIKAN UMUM
}

\author{
SUDADI
}

IAINU Kebumen

Abstract: This research starts from the general assumption that most of the Indonesian generation is dominated by Muslim communities who attend public schools rather than madrasa schools, whereas Islamic Religious Education (PAI) taught to students is more taught in madrasa schools. As a result, many Muslim students have a lack of understanding of religion and they do not understand perfectly (kaffah) about the values contained therein. Islamic education in public schools such as elementary schools to senior high schools must receive development, modification, innovation and additional learning programs so that the integral objectives of Islamic education can be achieved properly. A more optimal learning system can be done by broadly modifying PAl subjects. Besides, pesantren-based education launched in public schools is to create students to have higher moral character. This study discusses the development and learning process of PAl in public schools that implement pesantren-based school programs. This study aims to describe the pesantren-based schools by describing the planning, implementation, and evaluation of the learning system. The analytical approach in this study is naturalistic by conducting a comprehensive and descriptive discussion on the focus of research in an integrated education system, with observation and interview methods, followed by testing the validity of data through frequent interactions with primary sources, conducting more diligent observation and conduction triangulation tests. Besides, this research uses descriptive analysis, cross-case analysis and comparative and inductive reasoning for the discussion and analysis of findings. The results of this study explain that the application of pesantren-based Islamic religious education in public schools has good grades for students because students can practice and explore religious knowledge as they should.

Keywords: Islamic Education System, Islamic Boarding School.

Abstrak : Penelitian ini berawal dari anggapan umum bahwa sebagian besar generasi Indonesia didominasi oleh masyarakat muslim yang bersekolah di sekolah negeri bukan pada sekolah madrasah, sedangkan Pendidikan Agama Islam (PAl) yang diajarkan kepada siswa lebih banyak di ajarkan di sekolah madrasah. Akibatnya, banyak siswa siswi beragama Islam memiliki pemahaman yang kurang terhadap agama dan mereka tidak mengerti dengan sempurna (kaffah) tentang nilai-nilai yang terkandung di dalamnya. Pendidikan Islam di sekolah umum seperti sekolah dasar hingga sekolah menengah harus mendapat pengembangan, modifikasi, inovasi dan program pembelajaran tambahan sehingga tujuan integral pendidikan Islam dapat tercapai dengan baik. Sistem pembelajaran yang lebih optimal dapat dilakukan dengan memodifikasi mata pelajaran PAl secara luas. Selain itu, pendidikan berbasis pesantren diluncurkan di sekolah umum adalah untuk menciptakan siswa agar memiliki karakter moral yang lebih tinggi. 
Penelitian ini membahas tentang pengembangan dan proses pembelajaran PAI di sekolah umum yang menerapkan program sekolah berbasis pesantren. Penelitian ini bertujuan untuk mendeskripsikan sekolah berbasis pesantren dengan menguraikan perencanaan, pelaksanaan dan evaluasi pada sistem pembelajarannya. Pendekatan analisis dalam kajian ini bersifat naturalistik dengan melakukan diskusi secara komprehensif dan deskriptif pada fokus penelitian dalam system pendidikan terpadu, dengan metode observasi dan wawancara, dilanjutkan dengan menguji validitas data melalui interaksi yang sering dilakukan dengan sumber primer, melakukan obeservasi lebih rajin dan uji triangulasi konduksi. Selain itu penelitian ini mengunakan analisis deskriptif, analisis kasus silang dan penalaran komparatif dan induktif untuk pembahasan dan analisis temuan. Hasil dari penelitian ini menjelaskan bahwa penerapan pendidikan agama Islam berbasis pesantren di sekolah umum memiliki nilai yang baik bagi siswa, karena siswa mampu mempraktekan dan mendalami ilmu agama sebagaimana mestinya.

Kata Kunci: Pendidikan Agama Islam, Pendidikan Pesantren.

\section{A. PENDAhUluan}

Pendidikan adalah proses mentransformasikan pengetahuan yang ditujukan untuk perbaikan, penguatan dan menyempurnakan segala potensi yang ada pada peserta didik, pendidikan tidak harus diselenggarakan di ruang kelas dan dibatasi waktu belajar. Pendidikan dilakukan sepanjang hayat, kapan dan dimanapun manusia mau dan memiliki kemampuan melaksanakan proses pendidikan. Sepanjang sejarah umat manusia, peran pendidikan sangat segnifikan dalam upaya meningkatkan kualitas dan martabat hidupnya sehingga dari peradaban primitif dapat berkembang dengan luar biasa menuju peradaban modern.

Pendidikan dilihat dari pandangan klasik sebagai pranata yang menjalankan tiga fungsi sekaligus, pertama melalui pendidikan diharapkan generasi muda disiapkan untuk memegang peranan-peranan tertantu dalam masyarakat di masa datang. Kedua, mentransfer ilmu pengetahuan sesuai peranan yang diharapkan. Ketiga, mentransfer nilainilai (values) Untuk memelihara persatuan dan keutuhan masyarakat sebagai sarana berlangsungnya kehidupan masyarakat dan peradaban (langgulung, 1980, p. 92) Pendidikan Islam diakui keberadaannya dalam sistem pendidikan nasional Indonesia yang terbagi menjadi tiga hal. Pertama, pendidikan Islam sebagai lembaga, diakuinya keberadaan lembaga pendidikan secara eksplisit. Kedua, pendidikan Islam sebagai mata pelajaran, diakuinya pendidikan agama sebagai salah satu pelajaran yang wajib diberikan pada tingkat dasar sampai perguruan tinggi. Ketiga, pendidikan Islam sebagai nilai (value), yakni ditemukannya nilai-nilai islami dalam sistem pendidikan (Daulay, 2009, p. 44). 


\section{Siti Fatimah, Ahman, Nurhudaya}

Pendidikan Islam baik sebagai lembaga maupun sebagai materi, oleh para pengamat pendidikan Islam di Indosenia dikritik karena telah mempraktekan proses pendidikan eksklusif, dogmatik, dan kurang dalam hal aspek moralitasnya. Proses pendidikan seperti ini terjadi di lembaga-lembaga pendidikan Islam, seperti Madrasah, Sekolah Islam, dan pesantren. Indikatornya menurut M. Amin Abdullah, terlihat pada proses pendidikan dan pengajaran agama pada umumnya yang lebih menekankan sisi keselamatan kelompoknya sendiri dari keselamatan yang dimiliki dan didambakan oleh pihak lain di luar kelompoknya sendiri (Abdullah, 2000, p. 14).

Pendidikan Agama Islam ke depan masih harus melandasi dinamikanya pada teksteks transendental, sekalipun masa turunnya sudah lampau, dan mau mengkaji kemajuankemajuan pendidikan umat Islam masa silam serta mau bersandar setidaknya pada kaidah baru yang berbunyi "al-akhzu bi al-jadid al-aslah wa al-muhafazah ala al-qadim al-salih". (Mentransfer nilai-nilai baru yang lebih baik dengan tetap mempertahankan nilai-nilai lama yang baik) (Abdullah, 2000).

Pendidikan Islam saat ini sangat dibutuhkan karena adanya perubahan tatanan hidup manusia yang mengalami perubahan yang sangat cepat. Pendidikan Agama Islam ditujukan untuk membentuk manusia dengan kecerdasan intelektual dan spiritual. Tujuan seperti ini tidak mungkin terwujud tanpa adanya sistem dan proses pendidikan yang baik. Oleh karena itu, menurut pakar, pendidikan agama Islam ditujukan untuk mampu menciptakan manusia yang akan mengemban tugas menyejahterakan dan memakmurkan kehidupan di muka bumi ini.

Jika hal tersebut dikaitkan dengan kenyataan bahwa masyarakat Indonesia mayoritas beragama Islam, tentunya peningkatan kualitas dan kuantitas Pendidikan Agama Islam (PAI) dalam lembaga-lembaga pendidikan di Indonesia menjadi prioritas utama namun dalam implementasinya, banyak pemerhati pendidikan dan kaum agamawan menyoroti dan menilai peran dan fungsi PAI di sekolah-sekolah umum. Muhaimin menilai bahwa kurang efektifnya PAI di sekolah disebabkan sistem penyelenggaraannya yang bersifat mandiri, kurang efektif dalam menanamkan nilai-nilai yang bersifat kompleks. Guru PAI seharusnya bekerjasama dengan guru-guru lainya dalam kesehariannya. Pendidikan agama harus berintegrasi dan bersingkronisasi dengan pendidikan non-agama sehingga mempunyai relevansi terhadap berbagai perubahan sosial dalam masyarakat (Muhaimin, 2008, p. 107).

\section{B. METODE}

Dalam penelitian ini penulis menggunakan pendekatan kualitatif. Penelitian ini membahas tentang pengembangan dan proses pembelajaran PAI di sekolah umum yang 
menerapkan program sekolah berbasis pesantren. Penelitian ini bertujuan untuk mendeskripsikan sekolah berbasis pesantren dengan menguraikan perencanaan, pelaksanaan dan evaluasi pada sistem pembelajarannya. Pendekatan analisis dalam kajian ini bersifat naturalistik dengan melakukan diskusi secara komprehensif dan deskriptif pada fokus penelitian dalam system pendidikan terpadu, dengan metode observasi dan wawancara, dilanjutkan dengan menguji validitas data melalui interaksi yang sering dilakukan dengan sumber primer, melakukan obeservasi lebih rajin dan uji triangulasi konduksi (Suharsimi Arikunto, 2010: 274). Selain itu penelitian ini mengunakan analisis deskriptif, analisis kasus silang dan penalaran komparatif dan induktif untuk pembahasan dan analisis temuan

\section{PENDIDIKAN AGAMA ISLAM}

Istilah pendidikan adalah berasal dari kata didik, setelah mendapat awalan mesehingga menjadi mendidik memiliki arti memelihara dan memberikan latihan, sehingga untuk mencapainya memerlukan ajaran maupun tuntunan serta pimpinan tentang akhlak dan kecerdasan. Kata pendidikan setelah ditambah awalan dan akhiran dengan kata dasar sebelumnya didik, diartikan sebagai proses merubah sikap maupun tata laku seseorang ataupun sekelompok orang dalam upaya mendewasakan manusia dengan pengajaran dan pelatihan (Penyusun, Kamus Besar Bahasa Indonesia, 1989, p. 204). Dalam istilah Inggris pendidikan disebut education yang berasal dari kata educate (mendidik) artinya memberi peningkatan dan pengembangan. Education (pendidikan) diartikan dalam hal yang sempit sebagai proses perbuatan dalam memperoleh pengetahuan. Zuhairini menyatakan bahwa pendidikan agama sebagai berbagai usaha baik sistematis maupun pragmatis dalam upaya membantu peserta didik agar hidup berdasar ajaran Islam (Ramayulis, 2010, p. 27).

Secara teoritis pendidikan agama Islam lebih banyak ditunjukan terhadap perbaikan akan sikap mental yang diwujudkan dalam amal perbuatan, untuk diri pribadi ataupun orang lain. Sedangkan secara praktis, pendidikan agama Islam ialah pendidikan iman sekaligus pendidikan amal saleh, oleh karenanya pendidikan agama Islam berisi sikap maupun prilaku pribadi atau kelompok dengan bertujuan pada kesejahteraan hidup, maka hal ini menyangkut pendidikan individu dan masyarakat (Ramayulis, p. 27). Jalaluddin mendefinisikan pendidikan agama Islam adalah upaya yang dilakukan oleh mereka yang mempunyai tanggung jawab untuk membina, membimbing, mengembangkan serta mengarahkan potensi yang dimiliki anak agar mereka dapat berperan dan berperan dan berfungsi sebagimana hakekat kejadiannya (Jalaluddin, 2002, p. 19). 


\section{Siti Fatimah, Ahman, Nurhudaya}

Ahmad Tafsir berpendapat, Pendidikan agama Islam merupakan usaha yang dilakukan untuk mempunyai tanggung jawab dalam membina, mengembangkan serta mengarahkan potensi peserta didik agar dapat berperan dan berfungsi sebagaimana hakekat kejadiannya. Pihak yang dimaksud "mereka yang bertanggung jawab" dalam pengertian di atas adalah orang tua anak, dan guru serta pendidik lainnya merupakan pelimpahan dari sebagian tanggung jawab orang tuanya. Kemudian maksud dari ungkapan "agar mereka bisa memiliki fungsi dan peran sebagaimana hakekat kejadiannya" tidak lain adalah supaya yang dididik menjadi hamba Allah yang penuh pengabdian, taat dan setia sesuai dengan hakikat penciptaannya dan berperan sebagai khalifah Allah untuk memakmurkan kehidupan di dunia (Jalaluddin, p. 20). Secara ringkas, Pendidikan Agama Islam adalah upaya mengembangkan potensi mental spiritual dari peserta didik dengan menanamkan keimanan, mengajarkan ilmu pengetahuan Islam, membimbing mengamalkannya dan membimbing siswa memiliki akhlak mulia yang sesuai berbagai norma keislaman.

\section{PAI SEBAgAi MATA PELAJARAN}

Pendidikan Agama merupakan suatu mata pelajaran yang secara legal formal telah diakui secara sah dalam Undang-undang tentang Sistem Pendidikan Nasional No. 20 Tahun 2003. Bahkan ditegaskan bahwa isi kurikulum setiap jenis, jalur, dan jenjang pendidikan wajib memuat pendidikan agama yang sesuai dengan agama peserta didik. Undang-undang tersebut juga menjelaskan, bahwa kurikulum disusun sesuai dengan jenjang pendidikan dalam kerangka Negara Kesatuan Republik Indonesia (NKRI) dengan memperhatikan:
a. Peningkatan iman dan takwa
b. Peningkatan akhlak mulia
c. Peningkatan potensi, kecerdasan, dan minat peserta didik
d. Keragaman potensi daerah dan lingkungan
e. Tuntutan pembangunan daerah dan nasional
f. Tuntutan dunia kerja
g. Perkembangan ilmu pengetahuan, teknologi, dan seni
h. Agama
i. Dinamika perkembangan global
j. Persatuan nasional dan nilai-nilai kebangsaan (pasal 36 ayat 3)

Secara lebih spesifik juga dijelaskan lebih lanjut, bahwa kurikulum pendidikan dasar dan menengah wajib memuat:

a. Pendidikan agama 
b. Pendidikan kewarganegaraan

c. Bahasa

d. Matematika

e. Ilmu pengetahuan alam

f. Ilmu pengetahuan sosial

g. Seni dan budaya

h. Pendidikan jasmani dan olah raga

i. Ketrampilan/ kejuruan

j. $\quad$ Muatan lokal (pasal 37 ayat 1)

Kurikulum pendidikan tinggi wajib memuat:

a. Pendidikan agama

b. Pendidikan kewarganegaraan

c. Bahasa (pasal 37 ayat2) (Muhaimin, pp. 22-23).

Undang-undang ini juga menyatakan bahwa pendidikan agama adalah hak peserta didik, disebutkan; setiap peserta didik pada setiap satuan pendidikan berhak mendapatkan pendidikan agama sesuai dengan agama yang dianutnya dan diajarkan oleh pendidik yang seagama (pasal 12 ayat 1a). Dalam bagian penjelasan diterangkan pula, bahwa pendidik atau guru agama yang seagama dengan peserta didik difasilitasi dan atau disediakan oleh pemerintah atau pemerintah daerah sesuai dengan satuan pendidikan sebagimana diatur pasal 41 ayat (3). Dalam penjelasannya dinyatakan bahwa pendidikan agama merupakan usaha untuk membentuk peserta didik menjadi manusia yang beriman dan bertakwa kepada Tuhan Yang Maha Esa serta berakhlak mulia, dengan memperhatikan tuntutan untuk menghormati agama lain dalam hubungan kerukunan antar umat beragama dalam masyarakat untuk mewujudkan persatuan nasional (Muhaimin, p. 24).

Dalam GBPP PAI disekolah umum, dijelaskan bahwa PAI adalah upaya menyiapkan siswa dalam meyakini, memahami, menghayati, dan mengamalkan agama Islam dengan berbagai kegitan maupun bimbingan, dan pengajaran serta latihan tanpa meninggalkan toleransi terhadap agama lain sehingga kerukunan masyarakat dapat terbentuk demi terwujudnya persatuan nasional. Dari apa yang disampaikan tersebut maka hal yang harus diperhatikan dalam pembelajaran pendidikan agama Islam, yaitu berikut:

a. Pendidikan agama Islam merupakan upaya secara sadar, yaitu diperlukannya bimbingan,arahan,latihan-latihan yang terencana dalam proses pengajaran agar tujuan yang diinginkan dapat tercapai. 


\section{Siti Fatimah, Ahman, Nurhudaya}

b. Peserta didik yang hendak disiapkan dan atau dilatih dalam peningkatan keyakinan, pemahaman, penghayatan dan pengamalan terhadap ajaran agama Islam.

c. Pendidik atau Guru sebagai pengarah, pendidik dan pembimbing dalam pengajaran Agama Islam harus memberikan pemahaman, latihan-latihan, yang ditujukan untuk penghayatan dan pengamalan ajaran agama, agar terbentuk kesalehan dan kualitas pribadi untuk menuju terbentuknya kesalehan sosial sehingga tujuan pendidikan Agama Islam dapat tercapai

d. Kegiatan (pembelajaran) pendidikan agama Islam diarahkan untuk meningkatkan keyakinan, pemahaman, penghayatan dan pengamalan ajaran agama Islam dari peserta didik, yang disamping untuk membentuk kesalehan atau kualitas pribadi, juga sekaligus untuk membentuk kesalehan sosial. Dalam arti, melalui kualitas maupun kesalehan pribadi tersebut, diharapkan peserta didik mampu memilikihubungan kemasyarakatan yang baik, dapat membina hubungan yang baik dengan sesamamuslim maupun dapat menjaga toleransi terhadap mereka yang bukan seagama, dengan demikian persatuan dan kesatuan bangsa dapat terbina (Muhaimin, p. 76).

Proses pembelajaran pendidikan Islam di sekolah ditujukan agar kesalehan pribadi dan kesalehan sosial peserta didik dapat terwujud. Hal tersebut untuk menghindari sikap fanatisme dan intoleran pada peserta didik yang pada akhirnya sikap negatif tersebut dapat melemahkan kerukunan. Maka, pembelajaran diharapkan dapat menciptakan Ukhuwah Islamiyah, dalam arti luas yaitu ukhuwah fi al-'ubudiyah, ukhuwah fi alinsaniyah, ukhuwah fi al-wataniyah wa al-nasab, dan ukhuwah fi al-din al-Islam.

\section{Kurikulum PAI di Sekolah}

a. PAI Dalam Kurikulum KTSP

Mata pelajaran sebagai mata pelajaran, PAI merupakan upaya mewujudkan peserta didik yang beriman serta bertakwa dan berakhlak mulia melalui pengajaran, pelatihan dan bimbingan yang terencana bersumber pada AlQur'an dan Hadis, dan menjadikan peserta didik sebagai anggota masyarakat yang bertoleransi sehingga kerukunan dan persatuan bangsa dapat tetap terbina.

Mata mata pelajaran PAI sekarang masih menggunakan kurikulum 2006 yang juga disebut juga dengan Kurikulum Tingkat Satuan Pendidikan (KTSP). Kurikulum ini merupakan pengembangan dari kurikulum 2004 yang disebut dengan Kurikulum Berbasis Kompetensi (KBK) walaupun pada tahun 2016 mulai diuji coba Kurikulum 13. Mata pelajaran Pendidikan Agama Islam tersebut 
keseluruhannya terangkum dalam lingkup aspek al-Qur'an dan Hadis, Aqidah (keimanan), Akhlak, Fikih (ibadah), dan Tarikh Islam. Hal ini dapat tergambar bahwa cakupan PAI adalah keseimbangan, keselarasan maupun keserasian hubungan manusia dengan Allah SWT, sesama makhluk maupun manusia lain dan dengan lingkungannya (Penyusun, Kurikulum 2004, 2004, p. 7).

b. Teori Sistem Pembelajaran

Pengembangan dan pembelajaran ada beberapa aliran filsafat pendidikan mendasari usaha-usaha pemberdayaan PAI tersebut, Theodore Brameld, yang yang diintrodusir oleh $\mathrm{M}$. Noorsyam, mengklasifikasi empat aliran filsafat pendidikan, yaitu: Progresivisme, Esensialisme, Perenialisme, dan Rekonstrusionisme (Noorsyam, 1993, p. 224). Keempat teori tersebut memiliki kontribusi terhadap konsep pengembangan dan pemberdayaan pendidikan Islam (termasuk didalamnya adalah PAI). Aliran ini berpendapat bahwa pendidikan harus bersifat progresif dan dapat menghadapi amcaman keberadaan manusia. Karena pendidikan ditujukan untuk membangun pengalaman manusia terusmenerus (progresif). (Barnadib, 1982, p. 25) Dalam konteks PAI hal ini senantiasa relevan, karena pengembangan iman, takwa dan akhlak mulia mulai sangat penting sebagai bekal seorang muslim dalam menghadapi berbagai problem kehidupannya yang semakin kompleks.

Teori Esensialisme, berpandangan bahwa pendidikan harus bersendikan nilai-nilai yang tinggi dalam suatu kebudayaan. Fungsi pendidikan menjadi penjaga yang melestarikan (konservasi) nilai-nilai yang ada serta mensosialisasi nilai tersebut pada peserta didik. Oleh karenannya, pendidikan harus menjamin kestabilan dari nilai-nilai yang dipilih juga memiliki sistem jelas dan telah teruji (Barnadib, p. 25). Jika memperhatikan teori ini, tentu pembelajaran PAI untuk melestarikan nilai-nilai tinggi ajaran agama Islam agar senantiasa hidup dalam komunitas muslim dan terus-menerus diwariskan kepada tiap-tiap generasi. Karena nilai-nilai tersebut memiliki makna universal dan dapat membawa kebaikan yang penuh rahmat bagi umat manusia.

Teori Perenialisme, bersifat regresif yang berkeinginan untuk mengembalikan pendidikan kepada pemikiran filsafat dan kebudayaan yang menguasai abad pertengahan serta dipandang sebagai jiwa yang menuntun tata kehidupan manusia secara rasional (Philip W. Jackson , 1996). Aliran ini mengutamakan pembentukan kecerdasan dan tingkah laku intelektual sebagai fokus pendidikan yang diyakini sebagai kemampuan paling menentukan bagi 


\section{Siti Fatimah, Ahman, Nurhudaya}

kualitas manusia. Filsafat ini dapat dikatakan sebagai upaya revitalisasi budaya karena pengembangan kekuatan intelektual peserta didik diraih dengan cara mempelajari karya-karyanya. PAI yang dalam berbagai aspeknya selalu berusaha memadukan rasionalitas dan spiritualitas, berperan sebagai kekuatan pencerahan dalam menghadapi kehidupan global yang penuh tantangan sebagaimana yang pernah dialami Nabi Muhammad saw sewaktu menerima risalah keagamaan dari Allah harus menghadapi kegelapan peradaban jahiliyah di masa tersebut. Dalam konteks ini, pembelajaran PAI meningkatkan potensi-potensi akal yang dilandasi nilai-nilai transenden illahiyah guna mewujudkan insan kamil.

Rekonstruksionisme, sesuai dengan namanya memiliki konsep bersifat rekontruksi. Peserta didik diharapkan mengembangkan diri secara konstruktif sehingga dapat adaptif dengan tuntutan masyarakat. Dalam pendidikan, fungsi utamanya, sebagai alat untuk memperbaiki kehidupan masyarakat (rekonstruksi sosial). Teori "Rekontruksi Sosial" dalam hal-hal tertentu memberikan kontribusi terhadap pembangunan pendidikan nasional yang berdasarkan pada berbagai prinsip, antara lain adalah prinsip rekonstruksi sosial (Fasli Jalal dan Dedi Supriadi, 2001).

Mengenai keempat teori filsafat di atas, teori progresivisme dan rekonstruksi sosial bersifat kritis dan radikal, sedangkan esensialisme dan perenialisme lebih bersifat konservatif bahkan regresif. Konsep-konsep esensialisme dan perenialisme berguna bagi pengembangan dan pemberdayaan Pendidikan di sekolah dalam usaha memelihara dan mengembangkan nilai-nilai esensi dalam pembelajaran secara umum. Sedangkan progresivisme dan rekonstruksi sosial dapat memberikan kontribusi dalam pengembangan PAI yang dinamis, progresif, relevan dan adaptif dengan zaman dan lingkungan (Hamami, 2008, p. 40).

Paradigma pengembangan PAI menurut Muhaimin diklasifikasikan menjadi tiga, yaitu: 1) paradigma formisme, 2) paradigma mekanisme, 3) paradigma organisme (Et.al, 2008). Pandangan paradigma formisme merupakan kerangka dikotomis yang menempatkan Pendidikan Agama Islam di sekolah dalam posisi yang terpisah dengan disiplin ilmu yang lain. Pengembangan PAI hanya diorientasikan pada aspek-aspek spiritual, ukhrowi dan agama dalam pengertian sempit yang bersifat tektual normatif, serta kurang memperhatikan aspek dalam kehidupan manusia. Sehingga pengembangan PAI di sekolah 
berbentuk mata pelajaran yang terpisah dari yang lain (separated subject curriculum) (Nasution, 2001, p. 178).

Sedangkan dalam pandangan paradigma mekanisme menempatkan kurikulum PAI berhubungan dengan mata pelajaran lain di sekolah. Dalam model ini, suatu konsep yang ada dalam suatu mata pelajaran dikorelasikan dengan mata pelajaran yang lain (correlated curriculum) (Sukmadinata, 2001). Pola yang digunakan dengan memberikan nuansa keislaman pada mata pelajaran umum, demikian pula sebaliknya dalam PAI dimasukan nuansa sains dan teknologi sehingga keduannya terjadi korelasi (Hamami, p. 43)

\section{E. SISTEM PEMBELAJARAN PENDIDIKAN BERBASIS PESANTREN}

Pengertian pesantren secara umum dapat dilihat dari pengertian Adnan Mahdi yang mengemukakan :

"Pesantren is the oldest and unique iducational institution which has Indonesian characteristics, therefore, many studies have been conducted from different perspective, especially in the terms of periodisation of its history. However, the study appears to be so broad and described in general while correlating with the role of pesantren in the context of history of education in Indonesia. Based on the historical analysis through library research, the study shows that pesantren in Indonesia is periodically divided into five periods viz emergence, development, evolution, ideological fortress, and Muslims media development, While the role of pesantren is to be the source in formulating the national education system, preparing the educational and intellectual figures and the character education model.

Pernyataan tersebut mengandung makna bahwa pesantren merupakan lembaga pendidikan tertua dan unik berciri khaskan Indonesia. Periodisasi sejarah pesantren selama ini cenderung general dalam peran dan kiprahnya.

Menurut Zamakhsyari Dhofier, ada tiga alasan yang mendasari pesantren setidaknya menyediakan asrama bagi para santrinya: (1) kiai dan pengetahuan Islam yang mendalam menarik para santri dari jauh, dan ini berarti memerlukan asrama; (2) banyak pesantren berada di desa-desa di mana tidak tersedia perumahan santri, sehingga memerlukan asrama, dan (3) terdapat sikap timbal balik antara kiai dan santri, di mana para santri beranggapan kiai adalah bapak mereka, sedangkan kiai memandang santri sebagai titipan Tuhan yang harus selalu dilindungi (Dhofier, 1994, p. 47).

Adapun kitab-kitan Islam kalsik yang diajarkan di pesantren, menurut Nurcholis Madjid, dapat dibagi menjadi 7 kelompok, yaitu; (1) nahwu (syntax) dan sharaf 


\section{Siti Fatimah, Ahman, Nurhudaya}

(marphology), (2) Fikih, (3) aqa'id atau usuluddin, (4) tasawuf atau etika, (5) tafsir, (6) hadis, dan (7) bahasa Arab. (Madjid, 1997, pp. 7-11) Selain ketujuh kelompok tersebut, Dhofier menambahkan satu kelompok berbagai kitab Islam klasik yang juga diajarkan di pesantren, yaitu cabang-cabang kitab seperti tarikh dan balagah. Kitabkitab tersebut menurut Dhofier terdiri dari teks yang amat pendek dan ada juga teks yang terdiri dari berjilid-jilid tebal. Kesemuanya itu dapat digolongkan pula ke dalam tiga kelompok, yaitu: kitab-kitab dasar, kitab-kitab tingkat menengah, dan kitab-kitab besar (Dhofier, 1994). Dalam pembelajarannya, kitab-kitab Islam klasik tersebut secara bertahap, tentang tahapan pembelajaran ini, Steenbrink menggambarkannya sebagai berikut:

"Tingkat pertama adalah mempelajari bahasa Arab yang masih tersusun uraian pendek berbentuk sajak. Guru menyuruh siswa untuk menghafal teks dalam bahasa Arab tersebut tanpa salah dan selanjutnya guru akan menerangkan arti dan isinya kata demi kata.. Jika hal tersebut sudah dikuasai santri maka barulah dia mulai pelajaran agama yang sebenarnya. Yang pertama dan terpenting biasanya adalah fikih, tauhid atau ushuluddin dan tafsir al-Qur'an. Sesudah menyelesaikan pelajaran tersebut, para santri dapat mengambil mata pelajaran sampingan seperti tasawuf, hadis, hisab atau falak, yang semuanya tergantung pada keahlian yang dikuasai kiai pesantren tersebut".

Selain menggunakan tahapan-tahapan dalam proses pembelajaran, pengajaran kitab-kitab di pondok pesantren juga menggunakan metode yang unik. Adapun metode pembelajaran yang sering digunakan di pesantren adalah sorogan, dan wetonan. metode pembelajaran kitab secara individual, maupun menghafal beberapa pelajaran yang diberikan sebelumnya (Madjid, p. 28). Dengan metode ini, kiai mengetahui betul kemampuan para santrinya. Jika santri telah dianggap menguasai isi suatu pelajaran, maka kai akan menambahnya dengan materi baru, biasanya dengan membacakan, mengartikan, memberi penjelasan, dan lai-lain. Setelah itu, santri meninggalkan tempat tersebut untuk pergi ke tempat lain guna mengulang atau merenung kembali apa yang baru saja diberikan kepadanya.

Ada tiga tipe santri disetiap pesantren, Pertama, kelompok santri mukim memiliki waktu yang luas dan dapat membahas berbagai kitab Islam klasik dengan lebih mendalam dibawah bimbingan kiai yang memimpin pesantren. Kedua, mereka memperoleh kesempatan dan pengalaman hidup yang lebih saat tinggal di dalam

pesantren, baik dalam bidang pengajaran, organisasi atau hubungan dengan masyarakat dan pesantren-pesantren lainnya. Ketiga, mereka akan lebih fokus dengan 
studinya tanpa terbebani dengan tugas harian di rumah. Selain itu, karena jarak antara pesantren dengan rumah yang jauh, akan membuat para santri tidak mudah untuk pulang balik ke rumah mereka, meskipun mereka ingin pulang.

Dilihat dari komitmen dan berbagai nilai yang diajarkan kiai, maka santri dibagi menjadi tiga macam. Menurut Suteja, ketiga kelompok santri tersebut adalah: (1) santri konservatif, (2) santri reformatif, dan (3) santri transformatif (Siraj, 1999). Dikatakan santri konservatif, karena dengan cara masing-masing mereka berusaha membina dan menjaga berbagai nilai yang ada di pesantren. Santri model ini harus mengenal, mengamalkan serta patuh terhadap kaidah-kaidah keagama, kesusilaan, kebiasaan, dan aturan-aturan hukum tanpa kritisisme yang radikal. Berbeda dengan kelompok santri reformatif, yang berusaha mempertahankan dan memelihara kaidah-kaidah keagamaan, serta berusaha menggantikannya dengan bentuk dan model baru jika diperlukan. Argumen yang mereka ajukan adalah prinsip dan kata hikmah: almuhafazat ala al- qadim al-salih wa al-akhdz bi al-jadid al-aslah", dapat memelihara berbagai hal yang baik dan mampu mengambil berbagai hal baru yang lebih baik. Dan yang dimaksud dengan kelompok santri transformatif adalah mereka yang secara progresif melakukan lompatan budaya dan pemikiran intelektual, namun tetap memperhatikan nilai-nilai dan berbagai kaidah keagamaan yang mereka dapatkan dari pesantren. Hal ini direfleksikan dengan adanya pikiran untuk menantang status quo dan menawarkan berbagai perubahan yang strategis, terutama dalam rangka menangani persoalan umat dan bangsa.

Kata "kiai" dalam tradisi Jawa digunakan dalam dua hal, pertama, kata kiai bagi orang Jawa digunakan untuk menyebut kakeknya "yaitu" yang merupakan singkatan dari kiai. Dari penggunaan tersebut, kata kiai mengandung makna pensucian pada orang tua. Dalam makna ini, kata kiai juga digunakan untuk memberikan gelar kehormatan kepada para ulama. Oleh karenanya, sering di jumpai di masyarakat panggilan untuk orang-orang terhormat seperti: Ki Ageng, Ki Gede, dan Kiai Haji. Kedua kata kiai juga lazim digunakan untuk sesuatu yang sakral, keramat, dan sakti. Dari segi ini dijumpai di masyarakat Jawa ada panggilan untuk benda-benda yang dianggap sakral, keramat dan sakti seperti: Kiai Sabuk Inten, Kiai Nogo Sosro, dan Kiai Slamet. Dua kiai yang pertama digunakan untuk menunjuk keris yang dianggap sakral, keramat, dan sakti. Sementara kata kiai yang terakhir digunakan untuk menyebut seekor kerbau di keraton Solo yang dianggap sakral, keramat, dan sakti (Akaha, 2001, pp. 31-33). 


\section{Siti Fatimah, Ahman, Nurhudaya}

Kiai pesantren diyakini memilki barakah, karena mereka merupakan pewaris para Nabi. Barakah yang dimiliki kiai dapat dilihat dari kemampuannya dalam hal supranatural dan magis. Mereka dapat menyembuhkan orang sakit yang disebabkan oleh jin dan makhluk halus. Seseorang yang sakit juga dapat disembuhkan dengan hanya sentuhan kiai atau dengan diberikan air minum oleh kiai. Sementara itu, keluasan ilmu agama Islam yang dimiliki oleh kiai terlihat pada sejarah pendidikan dan silsilah intelektualnya. Ilmu kiai juga dapat diukur dari kemampuan berbicara dengan dengan lugas. Ia mampu menjelaskan masalah-masalah agama dalam kitabkitab klasik kepada para santri secara memuaskan. Selain ilmu, kelebihan kiai terletak pada kekuatan moralitasnya. Kekuatan moralitas kiai juga terletak dapat diukur dari kedekatannya dengan Allah SWT, terlindungi dari dosa-dosa kecil dan besar, serta kedekatannya dengan masyarakat.

Demikian, dapat dikatakan bahwa yang dimaksud dengan kiai di sini adalah seseorang yang memiliki kelebihan supranatural, keluasan ilmu agama Islam, dan kelebihan moralitas, yang dengan kelebihan-kelebihan tersebut ia dapat memengaruhi dan memberikan pendidikan kepada para santri yang belajar di pesantren khususnya dan masyarakat sekitar pesantren pada umumnya. Dalam dunia pesantren, kedudukan kiai sangat tinggi dan strategis. Ini terlihat dari kekuasaan dan kewenangannya yang mutlak dalam kehidupan di lingkungan pesantren. Karena kekuasaan dan kewenangannya itu tidak ada yang dapat melawan kekuasaan kiai, kecuali kiai lain yang lebih besar nama dan pengaruhnya di masyarakat. Kecenderungan seperti ini membuat para pengamat berkesimpulan bahwa kekuasaan dan kewenangan kiai di pesantren mirip dengan kekuasaan raja pada tradisi kerajaan pada masa lalu. Setidaknya ada dua faktor yang melatarbelakangi kedudukan kiai sangat otoritatif dan powerful sebagimana kedudukan raja, yaitu faktor intern dan ekstern. Secara internal, seorang kiai di pesantren lazimnya memiliki kepercayaan diri yang tinggi, baik dalam soal-soal pengetahuan Islam, maupun dalam bidang kekuasaan dan menejemen pesantren (Dhofier, p. 14).

Sementara itu secara eksternal seperti para santri, orang tua santri, dan masyarakat pada umumnya memandang kiai sebagai seorang yang memiliki kelebihan supranatural, intelektual, dan moral. Kepercayaan mereka terhadap kiai ini memiliki peran yang kuat di lingkungan pesantren khususnya dan di luar pesantren pada umumnya. Didunia pesantren dikenal kiai dan guru bantu. Kiai dipahami sebagai pemilik dan pengasuh para santri yang bertugas mengajarkan pelajaran-pelajaran agama, baik yang pokok maupun yang tambahan. Diantara yang termasuk pelajaran 
pokok adalah fikih, tauhid, dan tafsir al-Qur'an; sedangkan yang termasuk pelajaran tambahan adalah tawasuf, hadis, hisab atau falak. Sementara, guru bantu dipahami sebagai guru yang bertugas membantu kiai untuk mengajarkan beberapa cabang bahasa Arab kepada guru santri. Para guru bantu ini biasanya direkrut dari para santri yang sudah senior yang mendapatkan kepercayaan mengajar dari kiai. Selain mengajar, guru bantu juga bertugas untuk mengurusi kebutuhan harian para santri, menempatkan santri baru, menemui para orang tua santri yang mengunjungi anak-anak mereka di pesantren. Dan menggantikan tugas kiai pada saat ada uzur atau halangan. Para guru bantu inilah yang kelak di percaya oleh kiai untuk memimpin pesantren di luar daerah.

\section{F. KESIMPULAN}

Pendidikan PAI berbasis pesantren di lembaga pendidikan umum membantu siswa yang untuk bisa mendapatkan pengetahuan yang maksimal. Pendidikan Agama Islam merupakan landasan pendidikan keagamaan bagi umat Islam di Indonesia. Telah di sebutkan bahwa pendidikan keagamaan yang tercantum dalam undang-undang tentang Sistem Pendidikan Nasional No. 20 Tahun 2003. Bahwa isi kurikulum setiap jenis, jalur, dan jenjang pendidikan wajib memuat pendidikan agama yang sesuai dengan agama peserta didik. Pendidikan pesantren dalam hal ini dipilih sebagai alternatif pendidikan agama di lembaga pendidikan umum karena pendidikan pesntren mengajarkan kepada siswa tentang bagaimana siswa bersosialisasi dan bersikap layaknya hidup di masyarakat. Sehingga dengan menerapkan pendidikan berbasis pesantren siswa mampu mempraktekan dan mendalami ilmu agama sebagaimana mestinya serta siswa sudah siap untuk terjun dalam kehidupan nyata..

\section{DAFTAR PUSTAKA}

Abdullah, A. (2000). Pengajaran Kalam dal Teologi di Era Kemajemukan: Sebuah Tinjauan Materi dan Metode Agama" dalam Tashwirul Afkar. Refleksi Pemikiran Keagamaan dan Kebudayaan.

Akaha, A. Z. (2001). Bila Kiai Dipertuhankan: Membedah Sikap Beragama NU. Jakarta: Pustaka Al-Kautsar.

Barnadib, I. (1982). Filsafat Pendidikan Islam, pengantar Mengenai Sistem dan metode. Yogyakarta: FIP IKIP.

Basri, H. (2012). Kapita Selekta Pendidikan. Bandung: CV Pustaka Mulia.

Daulay, H. P. (2009). Dinamika Pendidikan Islam di Asia Tenggara. Jakarta: Rineka Cipta. 
Dhofier, Z. (1994). Tradisi Pesantren: Studi tentang Pandangan Hidup Kiai. Jakarta: LP3ES.

Et.al, M. (2008). Paradigma Pendidikan Islam. Bandung: Rosdakarya.

Fasli Jalal dan Dedi Supriadi. (2001). Reformasi Pendidikan dalam Konteks Otonomi Daerah. Yogyakarta: Adicita Karya Nusa.

Hamami, T. (2008). Pemikiran pendididikan Islam: transformasi kurikulum pendidikan agama Islam di sekolah umum. Yogyakarta: Pustaka Book Publisher.

Jalaluddin. (2002). Psikologi Agama. Jakarta: Raja Grafindo Persada.

langgulung, H. (1980). Beberapa Pemikiran tentang Pendidikan Islam. Bandung: AlMa'arif.

Madjid, N. (1997). Bilik-bilik Pesantren. Jakarta: Paramadina.

Muhaimin. (2008). Paradigma Pendidikan Islam. Bandung: Rosda Karya.

Nasution, S. (2001). Asas-asas Kurikulum. Bandung: Jermmars.

Noorsyam, M. (1993). Filsafat pendidikan Islam dan dasar Filsafat Pendidikan Pancasila. Surabaya: Usaha Nasional.

Penyusun, T. (1989). Kamus Besar Bahasa Indonesia. Jakarta: Kalam MUlia.

Penyusun, T. (2004). Kurikulum 2004. jakarta: Departemen Pendidikan nasional.

Penyusun, T. (2008). Himpunan Perundang-undangan Republik Indonesia tentang Sistem Pendidikan Nasional. Bandung: Nuansa Aulia.

Philip W. Jackson . (1996). Handbook Research on Curriculum. New York: Simon \& Sxhuster Macmillan.

Ramayulis. (2010). Ilmu Pendidikan Islam. Jakarta: Kalam Mulia.

Sanjaya, W. (2008). Perencanaan dan Desain Sistem Pembelajaran. Jakarta: Prenadamedia Grup.

Siraj, S. A. (1999). Pesantren Masa Depan: Wacana Pembaharuan dan Transformasi Pesantren. Bandung: Pustaka Hidaya.

Sukmadinata, N. S. (2001). Pengembangan Kurikulum Teori dan Praktek. Bandung: Rosdakarya.

Zuhairini, dkk. (2004). Metodik Khusus Pendidikan Agama. Jakarta: PT Bina Ilmu. 